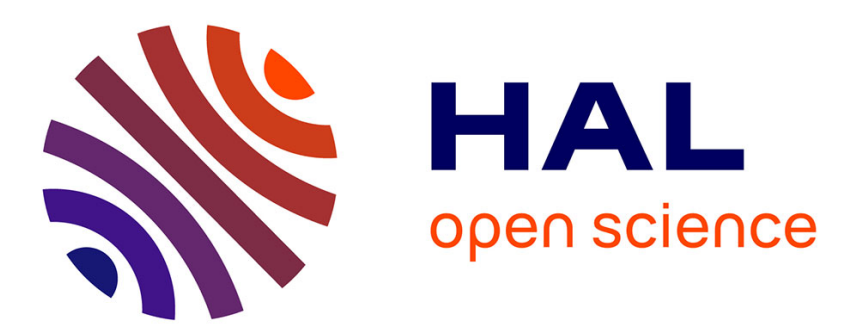

\title{
A model of chronic infrared laser thermal injury to the arterial wall
}

\author{
P. Douek, P. Lenz, F. Harmouch, A. Tabib
}

\section{To cite this version:}

P. Douek, P. Lenz, F. Harmouch, A. Tabib. A model of chronic infrared laser thermal injury to the arterial wall. Journal de Physique IV Proceedings, 1994, 04 (C4), pp.C4-245-C4-248. 10.1051/jp4:1994456 . jpa-00252719

\section{HAL Id: jpa-00252719 https://hal.science/jpa-00252719}

Submitted on 1 Jan 1994

HAL is a multi-disciplinary open access archive for the deposit and dissemination of scientific research documents, whether they are published or not. The documents may come from teaching and research institutions in France or abroad, or from public or private research centers.
L'archive ouverte pluridisciplinaire HAL, est destinée au dépôt et à la diffusion de documents scientifiques de niveau recherche, publiés ou non, émanant des établissements d'enseignement et de recherche français ou étrangers, des laboratoires publics ou privés. 


\title{
A model of chronic infrared laser thermal injury to the arterial wall
}

\author{
P.C. DOUEK, P. LENZ* , F. HARMOUCH and A. TABIB** \\ Laboratoire de Radiologie Expérimentale, URA 1216 du CNRS, 69394 Lyon cedex 03, France \\ ${ }^{*}$ INSERM U. 281 \\ ${ }^{* *}$ Service d'Anatomopathologie, Hôpital Cardiologique
}

INTRODUCTION

Restenosis at the site of interventional procedures for coronary artery disease remains a major, unsolved clinical problem (1). Recently we showed that pulsed infrared laser irradiation induced localized thermal lesions in rabbit arteries by transiently heating to $\sim 30^{\circ} \mathrm{C}$ above ambient temperature and subsequent smooth muscle cell (SMC) proliferation by 3-4 weeks (2) This study was undertaken to determine whether continuous wave $(\mathrm{CW})$ thermal-induced SMC proliferation could serve as a reliable experimental model of the cellular proliferative response to vascular injury and of the effects of potential therapeutic interventions.

\section{MATERIALS AND METHODS}

Over the $10 \mathrm{~cm}$ length used the central ear arteries of 6 male NZW rabbits were easily visualized, lying from $600 \mu \mathrm{m}$ (most proximal) to $330 \mu \mathrm{m}$ (most distal) below the skin surface. A Xe lamp delivered about one watt of $\mathrm{CW}$ infrared light (wideband, around $1 \mu \mathrm{m}$ ) transcutaneously to a $3 \mathrm{~mm}$ spot on the overlying skin. This led to reproducible heating. Using an exposure duration of 65 to 80 seconds, the surface heating could be varied but remained always below $100^{\circ} \mathrm{C}$ without ablative vaporization.

Thermal lesions $(n=71)$ were produced first distally, then proximally to prevent transient spasm occurring at one injury site from occluding flow at other sites subsequently treated in the same artery. Between adjacent lesions there was a zone $(\sim 5$ $\mathrm{mm}$ ) free of thermal injury that served as an internal control. All lesions were examined by histology at 21 days in order to determine the dose response of SMC proliferation to increasing thermal injury. All serial sections within a lesion were examined to determine the site of maximal SMC proliferation. Luminal and medial areas was determined by tracing the luminal perimeter and internal elastic lamina with a digitizing tablet. The maximal observed proliferative responses for each lesion are reported as mean \pm SD. 
RESULTS

Acute tissue response to CW infrared thermal injury: macroscopic study

Immediately after thermal injury, focal spasm of the artery was observed at the heated sites and spontaneously disappeared within a few minutes. Desiccation of the epidermis was also present. One day after dermal edema was associated with marked diffuse inflammation in a $2-3 \mathrm{~cm}$ wide band along the central artery and with vasodilatation of the collateral vessels. This inflammation resolved in 5-7 days. By 3 weeks the sites of dermal injury had healed and appeared nearly normal.

Chronic tissue response to CW infrared thermal injury: histological study

Transcutaneous CW IR irradiation of arteries without any ablation resulted in significant neointimal proliferation by three weeks (Figure 1 corresponding to an exposure of $80 \mathrm{sec}$ ) In all animals histopathologic features of the proliferative tissue appeared similar to those of early human restenoses observed in atherectomy specimens. Arterial segments midway between lesions were unaffected. Neointimal proliferation at 3 weeks following laser injury exhibited a dose dependence (Figure 2).

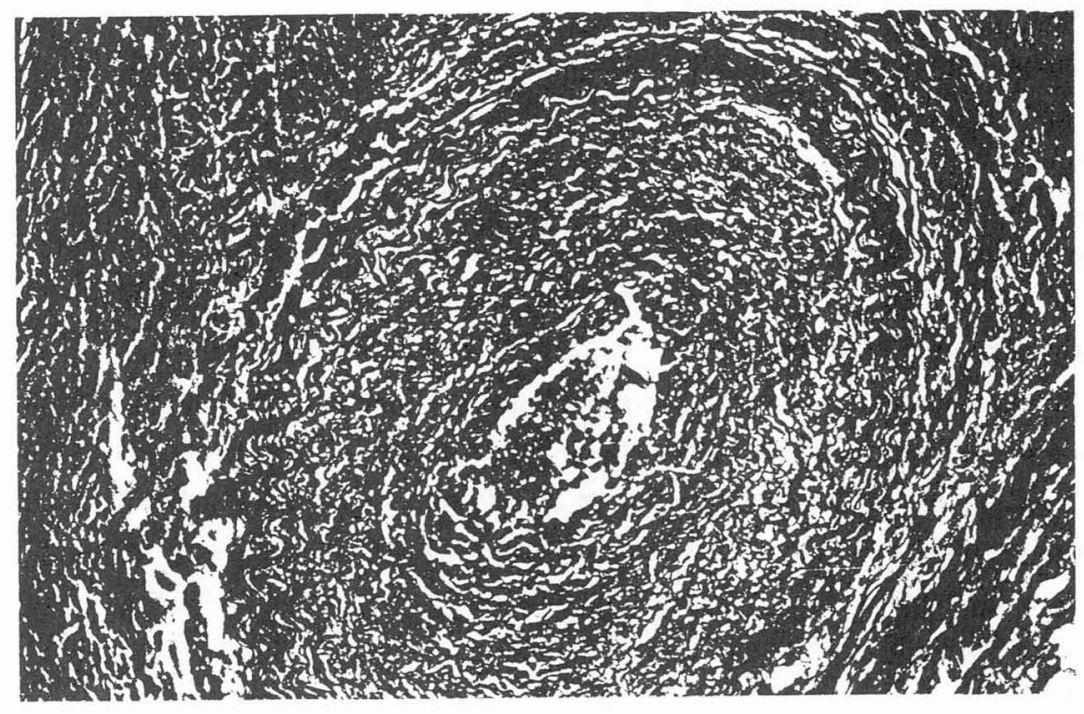

Figure 1 


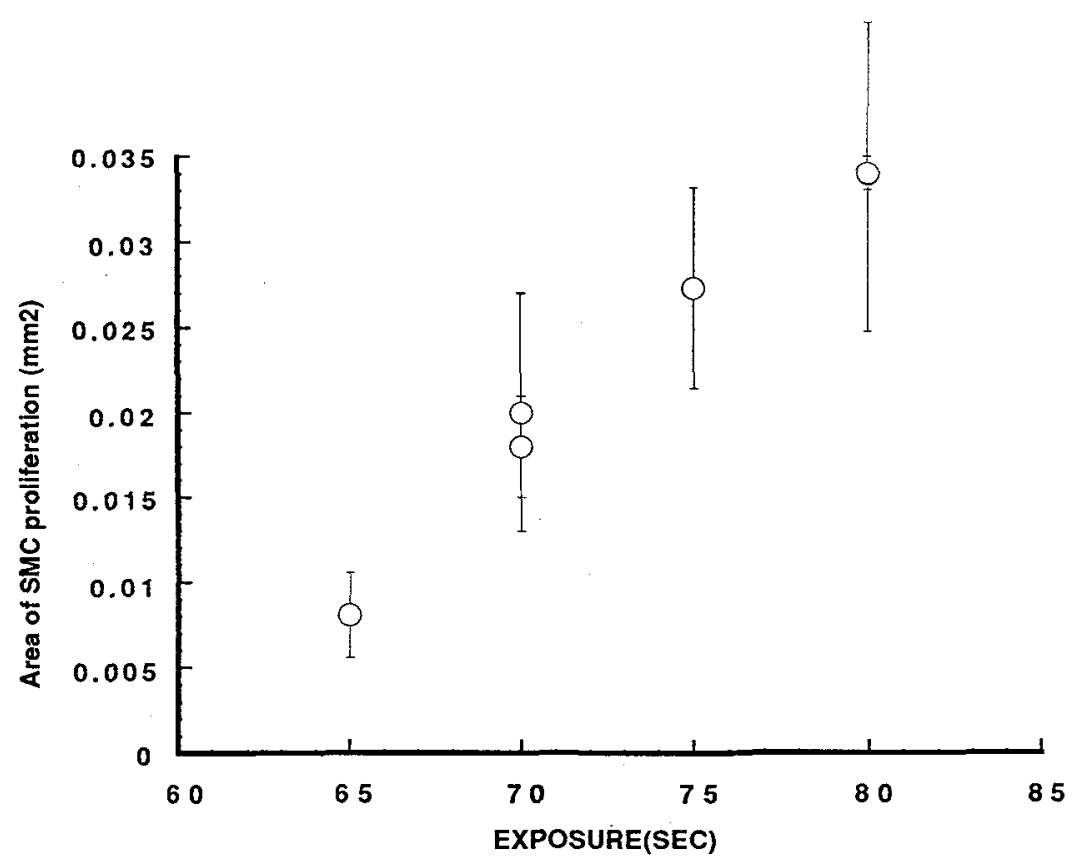

Figure 2

\section{DISCUSSION}

External crush injury and pulsed laser thermal injury of normal central arteries in the rabbit ear has been shown to result in reproducible, massive SMC proliferation (2). In order to determine the potential of CW thermal injury alone to induce SMC proliferation, we created a purely thermal injury in the same target vessel. The progression of SMC proliferation produced by thermal and by mechanical injury was remarkably similar, except that massive infiltration of polymorphonuclear cells in the interstitial tissue and severe medial necrosis was observed after thermal but not mechanical injury. Prevention of restenosis following angioplasty and other vascular interventions may require reduction of injury or, alternatively, reduction in SMC proliferation by adjunctive pharmacological therapy. Although many inhibitors of SMC have been proposed, their efficacy and/or dose response relationship has been difficult to quantify in animal models of restenosis. The thermally-injured rabbit ear artery model, although preliminary, may be particularly useful for screening a variety of proposed inhibitors. Many independent sites can be easily and reliably created in a single animal. 


\section{CONCLUSION}

Thermal injury to the arterial wall is a potent stimulus for SMC proliferation and may necessitate a reduction of the thermal energy used for angioplasty. Moreover, a relation exists between the degree of thermal injury and SMC proliferative response. This technique may be used as a practical model of restenosis suitable for screening therapies for inhibition of SMC proliferation.

\section{REFERENCES}

1 Holmes Dr, Vliestra RE, Smith HC, Vetrovec GW, Kent KW, Cowley MJ, Faxon Dp, Gruentzig AR, Kelsey SF, Detre KM, Van-Raeden M, Mock MB. Restenosis after percutaneous transluminal angioplasty (PTCA): A report from the PTCA registry of the National Heart, Lung, and blood institute. Am J Cardiol 1984;53:77-81C

2 Douek PC, Correa R, Shou M, Neville R, Banai S, Ferrans VJ, Epstein SE, Unger $E F$, Leon $M B$, and Bonner RF. "Dose-dependent smooth muscle cell proliferation induced by thermal injury with pulsed infrared lasers." Circulation 1992;861249-1256 